\title{
Pengembangan desain teko set gerabah kontemporer berbasis budaya lokal di Kabupaten Bojonegoro
}

\author{
Kristian Oentoro* \\ ${ }^{1}$ Program Studi Desain Produk, Universitas Kristen Duta Wacana, Yogyakarta, Indonesia
}

\begin{abstract}
Pottery is a type of traditional craft that has taken root in the history of art and culture of the Indonesian society. This fact is supported by various forms of ancient earthenware crafts which discovered since prehistoric times and the emergence of pottery craft centers in various parts of Indonesia, including in Rendeng Village, Malo District, Bojonegoro Regency. The changing of market needs and tastes today are a common problem faced by the traditional craft industry, including pottery crafts. Local wealth inside the traditional handicraft design which increasingly disappearing is one of the common concerns. The development of this contemporary pottery design aims to revive the skills of pottery craftsmen and the local culture of the Bojonegoro society in a modern design style. The research and development produced three sets of earthenware teapots, namely a turtle-shaped teapot set, a white combination of turtle-shaped teapot and teapot set inspired by Bojonegoro local coffee. Design research uses action research methods which consist of three design cycles. The application of this research method is useful to improve the capabilities and creativity of pottery craftmen in designing craft designs. Each design development cycle has four stages, namely planning, observation, action and reflection. The results of the study show that the color of the local clay Bojonegoro can characterize contemporary designs with a blend of colors and materials. The local way of drinking coffee as an inspiration for 'kothok' coffee teapots set has the potential to commercialize products and new experiences in drinking coffee.
\end{abstract}

Key words: teapot, pottery, contemporary, Bojonegoro

\begin{abstract}
Abstrak
Gerabah merupakan salah satu jenis kerajinan tradisional yang telah mengakar dalam sejarah seni dan kebudayaan masyarakat Indonesia. Hal ini didukung dengan berbagai bentuk kerajinan gerabah kuno yang ditemukan sejak zaman prasejarah dan munculnya sentra-sentra kerajinan gerabah di berbagai wilayah Indonesia, termasuk di Desa Rendeng, Kecamatan Malo, Kabupaten Bojonegoro. Perubahan kebutuhan dan selera pasar saat ini merupakan permasalahan umum yang dihadapi industri kerajinan tradisional, termasuk kerajinan gerabah. Kekayaan lokal dalam desain produk kerajinan tradisional yang semakin hilang merupakan salah satu kekhawatiran bersama. Pengembangan desain teko set gerabah kontemporer bertujuan untuk mengangkat kembali keterampilan perajin gerabah dan budaya lokal masyarakat Bojonegoro dalam gaya desain kontemporer. Penelitian dan pengembangan menghasilkan tiga set desain teko gerabah, yakni teko set bentuk kura-kura, teko bentuk kura-kura kombinasi warna putih dan teko set kopi kothok khas Bojonegoro. Penelitian desain menggunakan metode penelitian tindakan (action research) yang melalui tiga siklus perancangan. Penerapan metode ini juga bermanfaat untuk meningkatkan kemampuan dan kreativitas perajin gerabah dalam merancang desain kerajinan. Setiap siklus pengembangan desain memiliki empat tahap, yakni perencanaan, observasi, aksi dan refleksi. Hasil penelitian menunjukkan bahwa warna tanah liat lokal Bojonegoro secara artistik dapat menjadi ciri khas desain kontemporer dengan perpaduan warna dan material. Budaya minum kopi kothok yang menjadi inspirasi desain teko set juga memiliki potensi untuk mengkomersialkan produk dan pengalaman baru dalam meminum kopi.
\end{abstract}

Kata kunci: teko, gerabah, kontemporer, Bojonegoro

\section{Pendahuluan}

Keterampilan masyarakat dalam mengolah tanah liat menjadi kerajinan gerabah di beberapa daerah merupakan salah satu kearifan lokal yang dimiliki Indonesia. Seni kerajinan gerabah yang telah mengakar dalam sejarah kebudayaan masyarakat

\footnotetext{
* Corresponding author Tel : +62-819-0420-4080 ; e-mail : kristian@staff.ukdw.ac.id
} 
Indonesia dapat dibuktikan melalui temuan-temuan artefak berupa kerajinan gerabah kuno sejak ribuan tahun yang lalu. Gerabah dalam kajian arkeologi juga menjadi salah satu acuan dalam mengidentifikasi serta memetakan pemukiman manusia di masa lampau karena gerabah sebagai artefak dapat bertahan hingga ratusan tahun (Mochtar, 2013). Terdapat beberapa desa bersejarah di Indonesia yang merupakan penghasil kerajinan gerabah, seperti Desa Kasongan di Bantul, Desa Banyumulek di Lombok Barat, Desa Sitiwinangun di Cirebon, Desa Jipang di Gowa dan desa-desa lain penghasil kerajinan gerabah. Meskipun demikian, tidak banyak masyarakat Indonesia yang mengenal Desa Rendeng di Bojonegoro sebagai desa penghasil kerajinan gerabah yang memiliki berbagai keunikan seni dan budaya.

Desa Rendeng terletak di Kecamatan Malo, Kabupaten Bojonegoro, Provinsi Jawa Timur dan berada tepat di pinggiran Sungai Bengawan Solo. Salah satu keunikan demografi Desa Rendeng pernah terjadi pada tahun 1990-an, yaitu terdapat kurang lebih 80\% dari penduduk Desa Rendeng yang memiliki mata pencaharian sebagai perajin gerabah (Oentoro, 2018). Adapun jenis kerajinan gerabah yang paling banyak diproduksi oleh perajin gerabah di Desa Rendeng adalah celengan (Bahasa Jawa) yang berfungsi sebagai tempat untuk menabung uang. Kerajinan celengan gerabah Desa Rendeng banyak ditemui di pasar-pasar tradisional di Pulau Jawa dan sering disebut dengan celengan malo. Bentuk ikonik yang khas dengan kerajinan celengan malo adalah bentuk-bentuk hewan, seperti macan, singa, sapi, ayam, kura-kura, dan aneka hewan lain.

Seiring dengan perubahan kebutuhan pasar secara global maka penjualan celengan malo menjadi semakin menurun. Penurunan penjualan celengan malo juga menyebabkan berkurangnya jumlah perajin gerabah di Desa Rendeng dan beberapa studio kerajinan gerabah khususnya yang mengolah celengan malo terpaksa tutup. Meskipun beberapa perajin gerabah beralih pekerjaan, namun masih terdapat perajin yang bertahan dalam menekuni bidang usaha kerajinan gerabah. Para perajin gerabah yang masih produktif adalah perajin yang konsisten, memiliki keterampilan tinggi serta mewarisi usaha kerajinan gerabah secara turun temurun, salah satunya adalah Ismail (Gambar 1). Ia tidak hanya menguasai teknik cetak dalam memproduksi celengan malo yang dilakukan oleh perajin gerabah pada umumnya, namun ia juga menguasai teknik putar (throwing) untuk memproduksi produk gerabah sebagai peralatan makan, seperti cangkir, teko, piring, dan aneka gerabah lainnya.

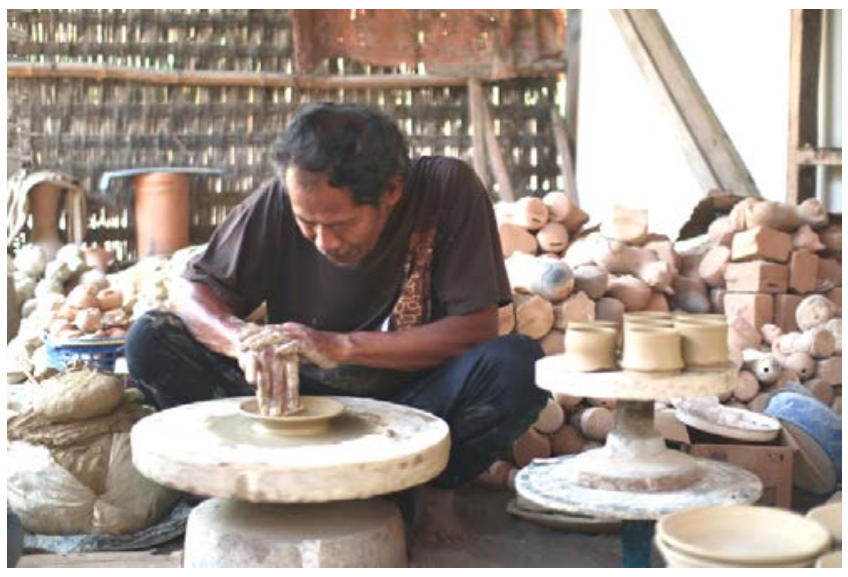

Gambar 1. Ismail, Perajin Gerabah Senior di Desa Rendeng Sumber : dokumentasi tim peneliti (Ariyasa, 2017)

Tempat produksi kerajinan gerabah Ismail di Desa Rendeng belum memiliki nama usaha, akan tetapi telah dikenal luas oleh masyarakat lokal. Ismail juga menjadi salah satu perajin gerabah di Desa Rendeng yang pertama kali membuat purwarupa maskot Kabupaten Bojonegoro, yakni Si Gogor.

Perubahan kebutuhan dan selera pasar telah dihadapi sebagai permasalahan umum bagi sebagian besar perajin gerabah di Desa Rendeng. Fenomena ini juga menjadi sebuah tantangan di bidang desain produk sehingga dibutuhkan penelitian dan pengembangan desain kerajinan gerabah yang bertujuan untuk membidik pasar yang lebih potensial. Arah pengembangan desain kerajinan gerabah dalam penelitian ini adalah teko set dengan gaya desain kontemporer. Teko set sendiri merupakan serangkaian pewadahan untuk menyajikan minuman teh atau kopi, pada umumnya terdiri dari teko dan dilengkapi dengan beberapa cangkir. Sedangkan penerapan gaya desain kontemporer pada desain teko set bertujuan untuk mengangkat kembali kerajinan gerabah lokal dalam tampilan desain masa kini. Melalui hasil observasi awal, masyarakat Bojonegoro juga memiliki tradisi dalam membuat sajian minuman kopi yang khas, disebut dengan kopi kothok. Pengembangan desain yang dilakukan juga bermanfaat dalam memperkenalkan dan mengangkat sajian kopi kothok sebagai inspirasi desain teko set.

\section{Bahan dan metode}

Penelitian dan pengembangan desain teko set gerabah menggunakan metode penelitian tindakan (action reseach) yang merupakan jenis penelitian berbasis pada data dan informasi yang didapat dalam proses pelaksanaannya. 
Penelitian tindakan dalam bidang perancangan juga sering dianggap sebagai riset praktisi yang membutuhkan refleksi kritis oleh diri peneliti (critical self-reflection) (McNiff, 2013). John W. Creswell telah memetakan beberapa karakteristik penelitian tindakan, yakni proses penelitian yang dinamis, fokus pada temuan yang bersifat praktis dan memiliki rencana untuk dalam setiap perancangan tindakan (Creswell, 2012). Penelitian tindakan juga dapat melibatkan orang lain secara kolaboratif dalam proses pelaksanaan yang dalam penelitian ini adalah perajin gerabah di Desa Rendeng. Keterlibatan perajin gerabah juga bermanfaat untuk meningkatkan kemampuan dan kreativitas perajin dalam mengembangkan desain kerajinan kontemporer.

Tujuan dari penelitian tindakan menurut Whitehead \& McNiff adalah untuk menghasilkan pengetahuan baru dan meningkatkan pemahaman melalui aksi atau kegiatan yang dilakukan selama proses pelaksanaan penelitian (Whitehead \& McNiff, 2006). Selain itu, penelitian tindakan juga berusaha memberikan penyelesaian masalah melalui serangkaian kegiatan penelitian yang dilakukan. Terdapat 3 siklus dalam pelaksanaan penelitian dan pengembangan desain teko set gerabah kontemporer yang dapat dilihat pada Gambar 2. Setiap siklus perencanaan dalam skema penelitian tindakan menghasilkan satu konsep desain teko set gerabah beserta purwarupa yang terus dikembangkan atau disebut dengan proses iterasi. Pengembangan desain dalam setiap siklus melalui 4 tahap, yakni tahap perencanaan (plan), tahap observasi (observe), aksi (action) dan refleksi (reflection).

Tahap perencanaan adalah proses mendeskripsikan dan menganalisa permasalahan yang dihadapi, kemudian menyusun rencana tindakan sebagai solusi. Sedangkan proses mengimplementasikan rencana tindakan atau melakukan perubahan dalam penelitian tindakan masuk ke dalam tahap aksi. Perubahan dalam penelitian yang dilakukan merupakan proses perwujudan dari konsep desain teko set gerabah yang dikembangkan dalam setiap siklus. Perubahan tersebut kemudian diamati kembali dalam tahap observasi agar mengetahui kelemahan dan kekuatannya. Hasil dan proses tersebut kemudian direfleksikan untuk menghasilkan pemahaman baru. Refleksi merupakan gerakan bolak-balik (shuttling back and forth) antara berpikir dan bertindak (Schön, 2017). Refleksi dalam penelitian tindakan juga berguna untuk meningkatkan kualitas pemikiran agar dapat mengambil keputusan terhadap langkah berikutnya yang akan dilakukan. Oleh karena itu, refleksi merupakan bagian inti dalam penelitian tindakan.

\section{Hasil dan pembahasan}

Memunculkan nilai-nilai kebaharuan dalam desain kerajinan tradisional sangat diperlukan oleh perajin dalam menjawab berbagai tantangan di era globalisasi. Aneka peralatan rumah tangga berbahan tanah liat bahkan mulai tergantikan dengan materialmaterial yang lebih praktis, kuat dan tahan lama (Eskak, Salma, \& Sumarto, 2017). Usaha kerajinan gerabah di Desa Rendeng, Kabupaten Bojonegoro juga tidak terlepas dari tantangan persaingan pasar kerajinan yang semakin ketat baik di Indonesia, maupun di tingkat internasional. Berbagai kerajinan tradisional di suatu daerah dapat menjadi objek yang mudah terpengaruh oleh globalisasi, terutama perubahan yang disebabkan oleh upaya untuk memenuhi kebutuhan ekonomi masyarakat atau karena adanya aktivitas pariwisata secara masif (Martono, 2010).

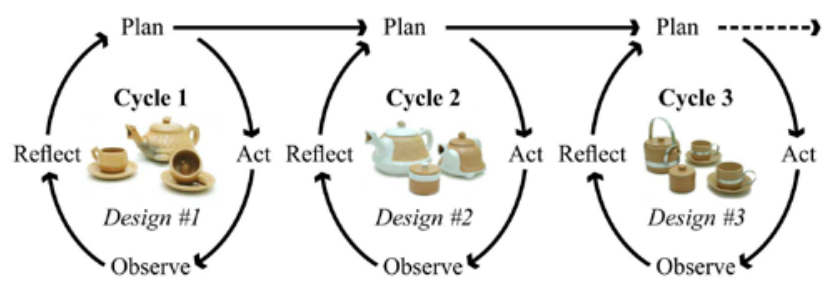

Gambar 2. Penerapan Metode Kaji Tindak (Action Research) Sumber : McNiff dalam Nugraha (2012)

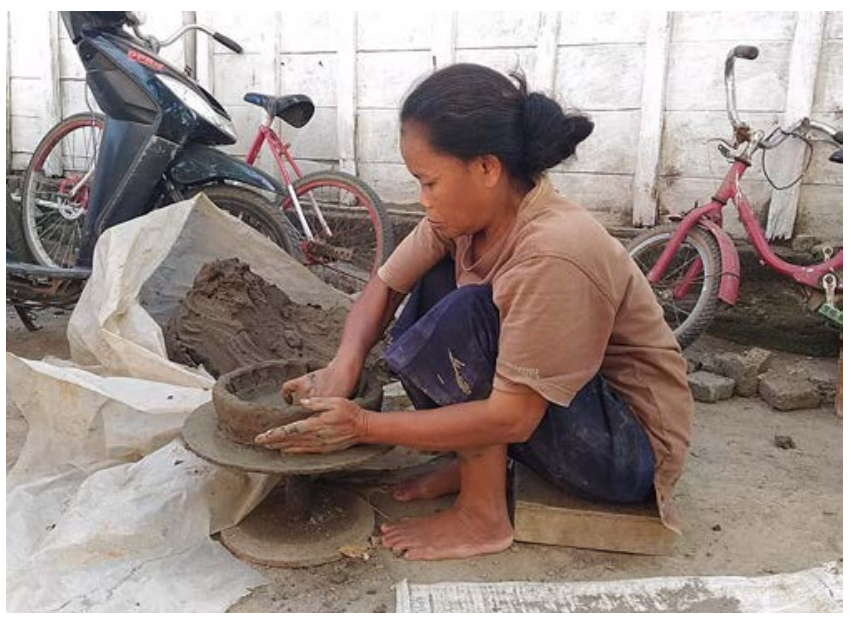

Gambar 3. Perajin gerabah tradisional di Desa Rendeng Sumber : dokumentasi tim peneliti 
Pengaruh persaingan pasar global dapat merubah bentuk kerajinan tradisional agar usaha mampu bertahan dan berkembang. Sedangkan dampak persaingan pasar yang dikhawatirkan adalah penurunan jumlah perajin gerabah tradisional di Desa Rendeng, mengingat sebagian besar perajin gerabah tradisional (Gambar 3) sudah lanjut usia.

Diversifikasi produk kerajinan dapat menjadi salah satu langkah strategis dalam menghadapi persaingan pasar. Selain bertujuan untuk meningkatkan nilai komersial, diversifikasi produk kerajinan juga dapat dilakukan untuk menciptakan desain kerajinan baru yang mampu menjawab kebutuhan dan selera pasar masa kini (Oentoro, 2018). Nilai-nilai kebaharuan dapat muncul melalui upaya kreatif untuk mengenali serta mengembangkan beberapa unsur yang membentuk desain kerajinan tradisional. Dalam disertasinya, Adhi Nugraha mengatakan bahwa terdapat 6 (enam) elemen dasar yang dapat digunakan dalam memetakan unsur-unsur desain kerajinan tradisional, yaitu teknik, utilitas, material, ikon, konsep dan bentuk (Nugraha, 2012). Keenam unsurunsur desain tradisional juga tidak terlepas dari budaya lokal yang mendorong terciptanya sebuah desain kerajinan tradisional, seperti kerajinan celengan malo di Desa Rendeng.

Berdasarkan hasil tahap observasi (observe) yang dilakukan dalam penelitian, terdapat dua teknik pengolahan gerabah tradisional di Desa Rendeng yang memiliki potensi untuk dikembangkan, yaitu teknik cetak dan teknik putar. Teknik cetak pada umumnya dikuasai oleh sebagian besar perajin gerabah dalam memproduksi celengan di Desa Rendeng, sedangkan teknik putar hanya dikuasai oleh sebagian perajin gerabah yang memiliki keterampilan tangan tinggi. Rata-rata perajin gerabah yang menggunakan teknik putar (Gambar 3) memiliki banyak pengalaman, mereka fokus pada pembuatan gerabah untuk peralatan rumah tangga. Berdasar hasil kajian sosiologi Fauziah menemukan bahwa keterampilan awal yang dikuasai oleh perajin di Desa Rendeng adalah membuat kerajinan gerabah untuk peralatan makan untuk memenuhi kebutuhan sendiri (Fauziah, 2017). Jenis-jenis peralatan makan gerabah lokal yang dihasilkan, seperti kendi, cowek, gentong, ngaron, layah, dlsb. Temuan ini juga menunjukan bahwa keterampilan perajin dalam membuat kerajinan celengan malo merupakan hasil pengembangan dari keterampilan awal.

Pengembangan desain teko merupakan salah satu upaya untuk mengangkat kembali keterampilan perajin dalam membuat kerajinan gerabah dengan teknik putar, sehingga proses perwujudan purwarupa desain teko set gerabah juga melibatkan perajin yang menguasai teknik putar. Meskipun teknik putar saat ini jarang dikuasai oleh perajin dari kalangan muda, akan tetapi rancangan desain dalam penelitian ini berusaha untuk memberi sentuhan masa kini atau kontemporer dalam pengembangan desain teko gerabah. Hasil dan pembahasan selanjutnya adalah uraian dari ketiga siklus pengembangan desain yang telah dilakukan menggunakan metode penelitian kaji tindak (action research).

\section{Pengembangan Desain ke-1}

Beranekaragam bentuk hewan yang digunakan sebagai inspirasi bentuk kerajinan celengan malo merupakan salah satu unsur bentuk yang diangkat dalam pengembangan konsep desain teko set gerabah pertama. Pada tahap perencanaan (plan), bentuk hewan kura-kura dipilih dari beragam bentuk hewan karena memiliki anatomi dan proporsi bentuk yang dimanfaatkan untuk desain teko. Melalui proses visualisasi desain teko inspirasi bentuk kura-kura (Gambar 4), ukuran cangkang yang lebih besar dari bagian tubuh lain dapat diterapkan untuk bagian ruang penyimpanan air, sedangkan bentuk kepala dapat dimanfaatkan untuk jalur air keluar. Inspirasi bentuk ekor kura-kura juga dikembangkan pada bagian genggaman teko dan cangkir.

Tahap perwujudan (act) purwarupa desain teko set gerabah dilakukan dengan menggunakan material tanah liat lokal Bojonegoro. Sepintas tingkat kecerahan warna tanah liat lokal bojonegoro terlihat seperti material keramik (Gambar 4.3.), meskipun hanya menggunakan suhu $\pm 800{ }^{\circ} \mathrm{C}$ dalam proses pembakaran menggunakan oven. Warna alami tanah liat lokal juga mencerminkan gaya desain kontemporer yang cenderung minimalis, sederhana dan terkesan bersih sebagai peralatan makan (tableware). Konsep bentuk kura-kura tidak hanya terdapat pada keseluruhan bagian teko, namun diterapkan juga pada genggaman penutup teko, motif badan teko dan alas cangkir sebagai detail produk. Gagasan kreatif juga tertuang pada dasar cangkir yang terdapat kura-kura kecil di dalamnya. Konsep kurakura yang berani tampil dalam perancangan desain cangkir berusaha memberikan kejutan kepada penikmat kopi atau teh ketika meminum sampai habis. Gambar 5 merupakan hasil perwujudan purwarupa pada siklus desain ke-1.

Berdasarkan hasil refleksi (reflect) pada tahap perwujudan, kekuatan dari desain ke-1 adalah keunikan desain teko berbentuk kura-kura yang merepresentasikan celengan malo sebagai identitas kerajinan gerabah Desa Rendeng. Bentuk teko dan cangkir gerabah juga terkesan menyatu dengan tema kura-kura. Meskipun terdapat detail kura-kura kecil di 

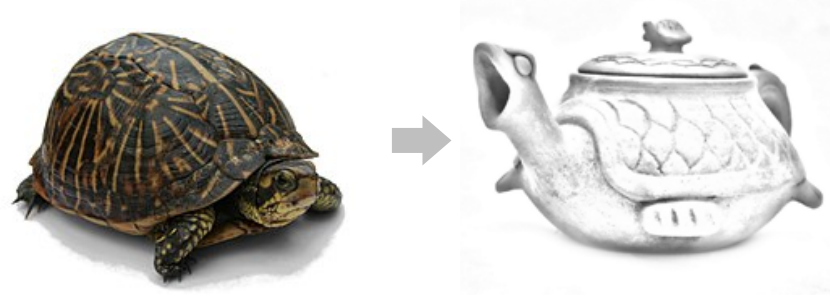

Gambar 4. Visualisasi desain teko inspirasi bentuk kura-kura Sumber : wikipedia.com (turtle) \& dokumentasi tim peneliti

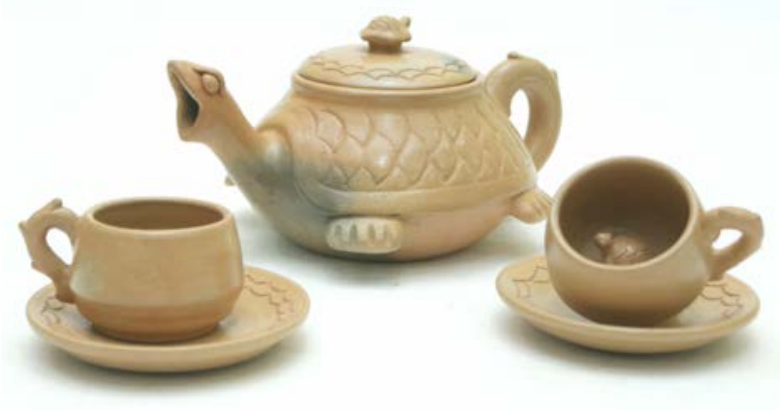

Gambar 5. Pengembangan Desain ke-1 : Teko Kura-Kura Sumber : dokumentasi tim peneliti

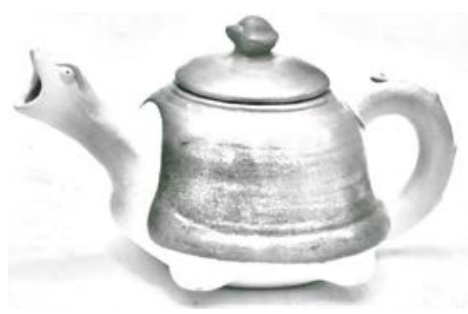

Gambar 6. Visualisasi pengembangan desain ke-2 Sumber : dokumentasi tim peneliti

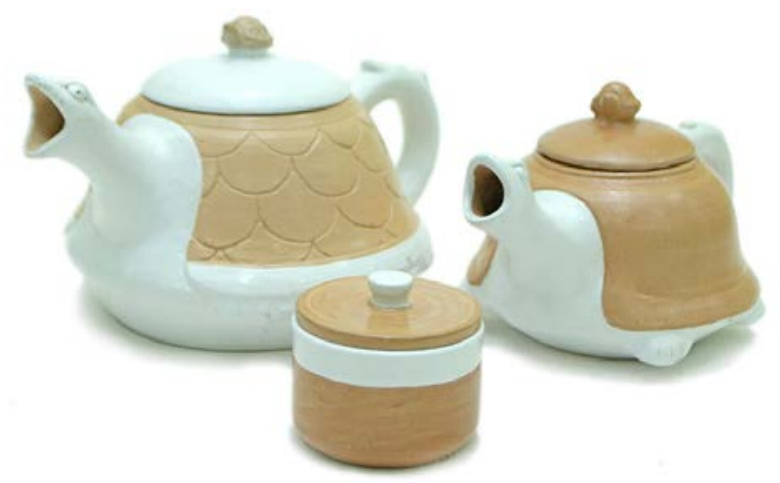

Gambar 7. Pengembangan Desain ke-2 : Teko Kura-Kura Putih Sumber : dokumentasi tim peneliti beberapa komponen teko yang menarik, namun cukup menyulitkan ketika produk dicuci atau dibersihkan. Hasil refleksi lain dari kelemahan desain ke-1 adalah dimensi teko kura-kura yang terlalu besar sehingga menyebabkan teko terlalu berat apabila diisi air. Oleh karena itu, diperlukan perbaikan pada perencanaan dan pengembangan desain berikutnya.

\section{Pengembangan Desain ke-2}

Perencanaan desain ke-2 tetap mengembangkan desain teko dari inspirasi bentuk kura-kura. Dimensi teko pada desain ke-2 diperkecil, termasuk mengurangi ketebalan dinding teko. Beberapa perubahan yang dilakukan bertujuan untuk mengurangi beban teko dan menyesuaikan dengan proporsi bentuk. Meskipun perubahan bentuk pada desain teko tidak signifikan dari desain sebelumnya (Gambar 6), namun perubahan lebih mengarah pada penyederhanaan bentuk. Kesederhanaan dalam desain produk dapat dilakukan pada bentuk dan struktur produk, serta material dan warna yang digunakan (Su \& Hao, 2010). Kesederhanaan bentuk juga merupakan salah satu karakteristik desain masa kini.

Selain berusaha menyederhanakan desain teko berbentuk kura-kura, pengembangan desain ke-2 juga memberikan sentuhan warna putih untuk menambah kesan kontemporer. Perpaduan warna putih dan warna asli tanah liat lokal Bojonegoro pada desain teko membuat komposisi yang menarik secara visual (Gambar 7). Berdasar hasil kajian psikologi J. Suresh Kumar, warna merupakan aspek yang mempengaruhi keputusan konsumen dalam memilih produk yang hendak dibeli (Kumar, 2017). Pemilihan warna yang tepat dalam produk juga sangat penting dalam pemasaran. Meskipun warna dapat dikaji dari aspek psikologi konsumen, namun makna dari sebuah warna juga sangat dipengaruhi oleh konteks budaya. Warna putih dalam perspektif budaya Amerika dan Timur Tengah menandakan kemurnian (purity), sedangkan di negara China dan Jepang menandakan suasana berkabung. Penerapan warna putih pada desain teko gerabah tentunya merujuk pada kesan murni, bersih dan higienis. Gambar 7 adalah hasil pengembangan desain teko ke-2.

\section{Pengembangan Desain ke-3}

Kopi kothok sebagai minuman khas masyarakat Bojonegoro merupakan inspirasi utama dalam konsep pengembangan desain ke-3. Gagasan desain teko ke-3 muncul dari hasil observasi yang dilakukan ketika mengumpulkan informasi terkait pengguna teko di warung-warung kopi lokal. Penyebab kopi kothok berbeda dengan kopi pada umumnya adalah dari 
proses pembuatannya, kopi kothok dibuat dengan cara merebus air dan kopi secara bersamaan sehingga aroma maupun rasa kopi semakin pekat. Kopi kothok yang disajikan pada saat panas juga membuat aroma dan rasa kopi semakin nikmat. Budaya meminum kopi kothok ketika masih panas juga berbeda, yakni dengan menuangkan kopi panas pada alas cangkir dan menyeruput sedikit demi sedikit. Tujuan menuang kopi panas yang ke alas cangkir adalah mempercepat proses penurunan suhu air ketika diminum.

Hampir seluruh warung kopi di Bojonegoro yang menyediakan kopi kothok menggunakan cangkir berbahan keramik. Genggaman cangkir keramik relatif kecil dan tipis, sehingga mudah patah ketika dipakai berulang kali dan menerima suhu air kopi yang panas. Pemilik warung kopi pada umumnya tidak membuang cangkir tersebut, melainkan memperbaiki genggaman yang patah ke tukang reparasi cangkir. Cara memperbaiki kerusakan cangkir adalah dengan memasang plat besi sebagai pengganti genggaman yang patah. Gambar 8 menunjukkan bentuk modifikasi cangkir kopi kothok yang menjadi inspirasi dalam pengembangan desain ke-3.

Selain menerapkan inspirasi bentuk modifikasi cangkir kopi kothok, pengembangan desain ke-3 juga menerapkan perpaduan material tanah liat lokal dengan plat besi (Gambar 9). Berdasarkan hasil refleksi terhadap kekurangan desain ke-2, maka genggaman teko yang sebelumnya berada pada bagian belakang teko dipindah pada bagian atas penutup teko. Posisi ini juga bertujuan mempermudah pengguna dalam menuangkan teh atau kopi ketika digunakan. Bagian alas cangkir juga dibuat sedikit mengerucut pada salah satu sisi, sehingga penikmat kopi lebih mudah ketika menikmati kopi dengan cara diseruput dari alas cangkir.

Pengembangan pada siklus terakhir desain teko set gerabah menghasilkan purwarupa yang terlihat menarik secara visual. Hasil refleksi desain ke-3 menunjukan bahwa perpaduan material tanah liat lokal dan plat besi merupakan kekuatan dan merupakan salah satu bagian yang menjadi daya tarik. Genggaman teko setelah dicoba juga lebih nyaman dibandingkan pengembangan sebelumnya. Modifikasi genggaman teko dan cangkir menggunakan plat besi juga memberikan konsep untuk memberikan identitas budaya lokal masyarakat Bojonegoro dalam sebuah desain teko set. Kekurangan dari pengembangan desain ke-3 lebih pada kesulitan dalam membersihkan bagian antara plat besi dan tanah liat, akan tetapi kesulitan ini juga ditemui pada cangkir kopi kothok pada umumnya.
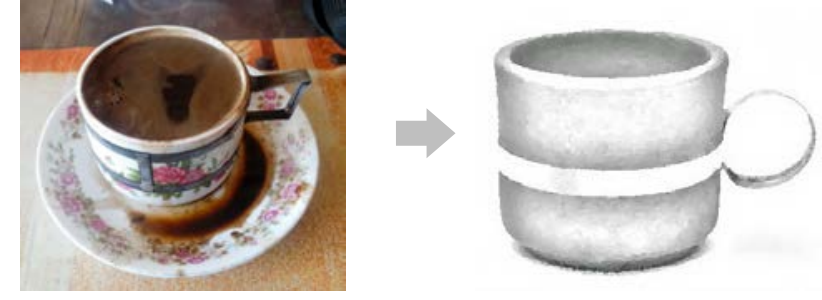

Gambar 8. Cangkir Penjual Kopi Kothok sebagai Inspirasi Desain ke-3

Sumber : dokumentasi tim peneliti

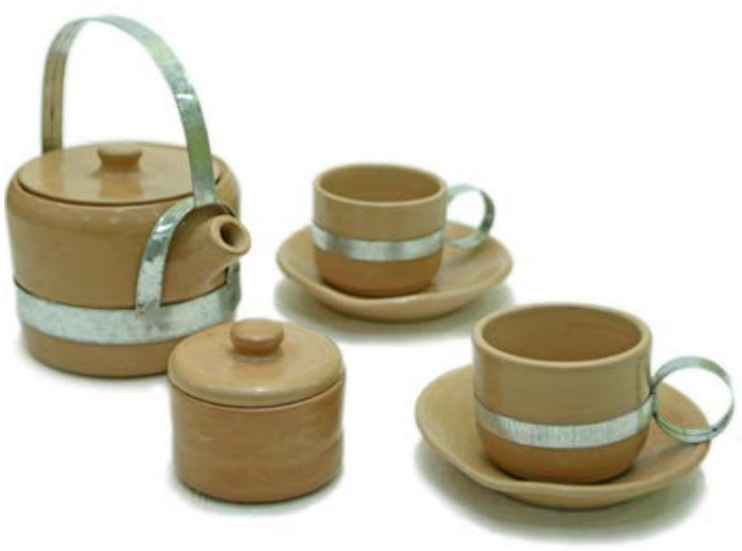

Gambar 9. Pengembangan Desain ke-3 : Teko Kopi Kothok Sumber : dokumentasi tim peneliti

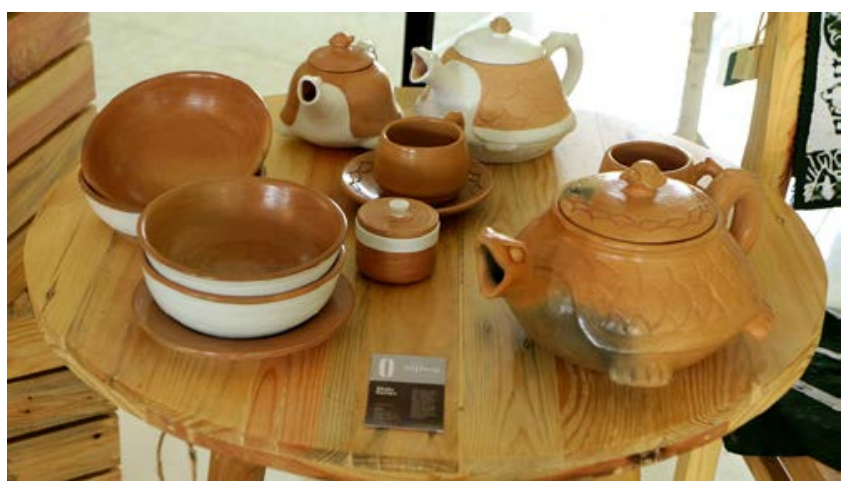

Gambar 10. Pameran Desain Teko Set Gerabah (Desain ke-1 \& ke-2)

Sumber : dokumentasi tim peneliti

Pengembangan desain teko set yang dihasilkan dalam penelitian dan pengembangan ini juga dipamerkan untuk mengetahui potensi nilai komersial dan respon konsumen. Pameran yang digelar selama 3 hari ini dihadiri oleh masyarakat, pengusaha, dan pegawai Pemerintah Daerah Kabupaten Bojonegoro. Hasil pengembangan desain teko set juga ditata dan didukung dengan dekorasi agar menarik minat konsumen, seperti pada Gambar 10.

Selain menampilkan hasil pengembangan desain ke-1: Teko Kura Natural \& ke-2: Teko Kura-Kura Putih, dalam pameran desain juga menampilkan hasil 


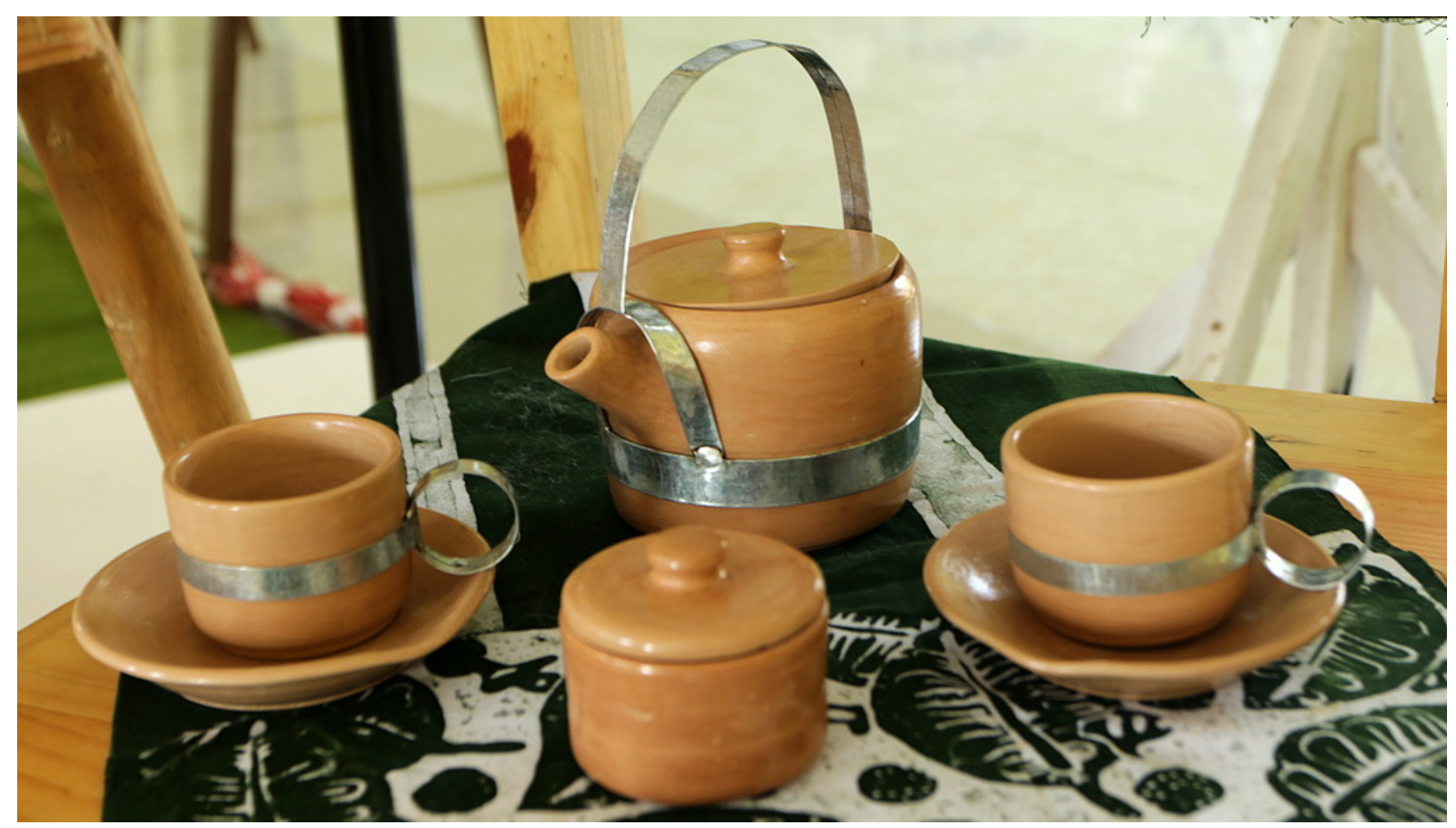

Gambar 11. Pameran Desain Teko Set Gerabah (Desain ke-3) Sumber : dokumentasi tim peneliti

Tabel 1. Harga Jual Teko Set

\begin{tabular}{llc}
\hline No. & Nama Barang & Harga Jual \\
\hline 1 & Teko Kura Natural & Rp. 126.000,- \\
2 & Teko Kura-Kura Putih & Rp. 136.000,- \\
3 & Kopi Kothok & Rp. 112.000,- \\
\hline & & Sumber : peneliti
\end{tabular}

pengembangan desain ke-3, yakni Teko Kopi Kothok (Gambar 11). Berdasarkan hasil wawancara kepada pengunjung pameran, ketiga desain mampu menarik minat konsumen untuk membeli, khususnya dari kalangan ibu-ibu dan pemilik kafe.

Ketiga desain teko set juga diberi label dan harga produk sebagai studi kelayakan pasar. Tabel 1 memperlihatkan hasil perhitungan harga jual yang ditawarkan saat pameran.

\section{Kesimpulan}

Berdasarkan hasil penelitian tindakan yang telah dilakukan, maka desain teko set gerabah merupakan salah satu jenis produk yang memiliki potensi untuk meningkatkan nilai komersial kerajinan gerabah di Desa Rendeng. Meskipun proses pembuatan sedikit juga menyimpan unsur-unsur desain tradisi yang dapat disimpulkan bahwa ciri khasnya terdapat pada unsur bentuk, teknik dan material. Ketiga unsur desain tradisi ini memegang peranan penting dalam pengembangan desain kerajinan gerabah berikutnya. Ciri khas bentuk yang menjadi acuan dalam pengembangan desain kerajinan gerabah di Desa Rendeng adalah aneka karakter hewan pada celengan.

Di samping itu, teknik produksi yang populer di Desa Rendeng adalah teknik cetak, namun dalam pengembangan desain memerlukan pembuatan purwarupa dengan menggunakan teknik putar (throwing). Skema produksi berikutnya, perajin dapat mengkombinasikan antara teknik cetak dan bentuk sehingga desain teko set akan lebih mudah dan cepat diproduksi. Sedangkan dalam unsur material, tanah liat lokal Bojonegoro secara visual memiliki nilai keindahan yang tinggi dan selaras dengan warna cerah, seperti putih dan/atau kombinasi dengan logam. Perpaduan warna maupun material ini yang menimbulkan kesan kontemporer dalam perancangan ini. Tanah liat lokal yang berada di Desa Rendeng juga berbeda dengan yang ada di Kasongan, Banyumulek, dan desa gerabah lainnya. Beberapa perajin sudah menyadari potensi tersebut, akan tetapi 
beberapa perajin masih kurang percaya diri ketika menggunakan material tanah liat lokal.

\section{Daftar pustaka}

Creswell, J. W. (2012). Educational Research: Planning, Conducting and Evaluating Quantitative and Qualitative Research (4th ed.). Boston: Pearson Education, Inc.

Eskak, E., Salma, I. R., \& Sumarto, H. (2017). Peningkatan kecerahan dan daya rekat warna pada produk gerabah batik. PRODUCTUM Jurnal Desain Produk (Pengetahuan Dan Perancangan $\quad$ Produk), $3(1), \quad$ 1-8. https://doi.org/10.24821/productum.v3i1.1733

Fauziah, S. (2017). Home Industri dan Perubahan Sosial (Studi Tentang Kerajinan Gerabah dan Perubahan Masyarakat di Desa Rendeng Kecamatan Malo Kabupaten Bojonegoro). Skripsi. Tidak Diterbitkan. Surabaya: Program Studi Sosiologi, FISIP UIN Sunan Ampel Surabaya.

Kumar, J. S. (2017). The Psychology of Colour Influences Consumers' Buying Behaviour-A Diagnostic Study. UshusJournal of Business Management, 16(4), 1-13.
Martono. (2010). Nilai-nilai tradisi sebagai inspirasi pengembangan desain kriya kontemporer. Jurnal Imaji, 8(1), 22-32.

McNiff, J. (2013). Action research: Principles and practice. New York: Routledge.

Mochtar, A. S. (2013). Temuan fragmen gerabah sebagai indikasi permukiman kuno di situs Borobudur. Berkala Arkeologi, 33(2), 211-226.

Nugraha, A. (2012). Transforming Tradition: A Method for Maintaining Tradition in a Craft and Design Context. Disertasi. Tidak Diterbitkan. Finlandia: Aalto University.

Oentoro, K. (2018). Diversifikasi produk Celengan Malo sebagai upayarevitalisasi kerajinan gerabah tradisional di Desa Rendeng, Kabupaten Bojonegoro. In Prosiding Seminar Nasional PIPT IV Buku 2 (pp. 25-31).

Schön, D. A. (2017). The reflective practitioner: How professionals think in action. New York: Routledge.

Su, H., \& Hao, N. (2010). The principles for modern product design. In Proceedings of the 2010 International Conference on Information Technology and Scientific Management.

Whitehead, J., \& McNiff, J. (2006). Action research: Living theory. London: SAGE Publications, Inc. 